A.

\title{
Research Note: Prospects for promotion of pea production technology in Kota region Rajasthan
}

\section{N.R. MEENA, F.L. SHARMA AND NARPAT SINGH}

Article Chronicle:

Received :

27.02.2016;

Accepted :

30.04.2016
SUMMARY : The findings indicated that establishment of good marketing network in nearby village, minimum support price of govt. should be declared for pea crop, development of multi-chamber cold storage units in cluster of villages, training on post-harvest technology be imparted to the farmers, cooperative farming in pea cultivation be promoted and kisan call centre should be established at zonal level were positively viewed by marginal and small farmers as future possibilities for promotion of pea production technology in the study area.

How to cite this article : Meena, N.R., Sharma, F.L. and Singh, Narpat (2016). Prospects for promotion of pea production technology in Kota region Rajasthan. Agric. Update, 11(2): 178-180 (DOI : 10.15740/HAS/AU/11.2/ 178-180).

KEY WoRds:

Pea, Prespects,

Promotion, Farming,

Marketing

\section{N.R. MEENA}

Department of Extension

Education, Rajasthan

College of Agriculture,

Maharana Pratap

University of Agriculture

and Technology,

Email: nrmeena1985@

gmail.com

See end of the article for

authors' affiliations 